\title{
STUDY ON MORPHOLOGICAL CHARACTERISTICS OF DIFFERENT GENOTYPES OF GLADIOLUS FLOWER
}

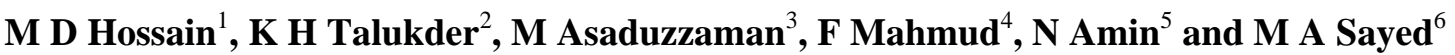

\begin{abstract}
The experiment was carried out during the period from November'2008 to October, 2009 to compare the morphology of five gladiolus flowers genotypes with respect to plant height, length and breadth of leaf, number of leaves per plant, length of flowers, breadth of flower, weight of flower, weight of single stick, length of spike, length of rachis, flowers per plant, days to reach $50 \%$ spike initiation, number of corm and cormel per plant, breadth of corm and weight of cormel per plant. The results indicated the significant variation amongst the gladiolus genotypes with respect to studied morphological characteristics as well as with yield, yield attributes and plant height. The plant height was higher $(58.6 \mathrm{~cm})$ and lower $(46.52 \mathrm{~cm})$ in yellow and orange /red respectively due to genotype. The lengths of leaves were almost same but higher with yellow and violet $(42.25 / 42.05 \mathrm{~cm})$ than the white and orange ones where the smallest length was recorded for red $(33.36 \mathrm{~cm})$ one. Almost same trends were recorded for breadth of leaves with the exception of few. The average number of leaves was highest for white (12.25) followed by red, violet, orange and yellow respectively. Most of the parameters of flower characteristics did not maintain regular trend and correlation when considered in terms of sequences starting from white to red as shown in the table 1, 2 and 3 . The recorded results clearly indicate that the white genotype has the best planting materials which may be planted for luxuriant growth of plants and production of excellent flowers.
\end{abstract}

Keywords: Gladiolus, Genotype, Morphology, Corm \& Cormel.

\section{INTRODUCTION}

Gladiolus was introduced in Bangladesh around 1992 from India (Mollah et al., 2002). It has recently been become popular in Bangladesh. Its demand has been increasing day by day with the advancement of aristocracy and modernization in Bangladesh. Commercial cultivation of gladiolus is gaining popularity due to export potentials and prevalence of favorable growing conditions in different parts of the country having some suitable factors. But the large scale production is practiced mostly during the winter season. Gladiolus flowers have occupied the importance in Bangladesh for three main considerations namely aesthetic, economic, and social. Considering the present status, it deserves necessity for future improvement both for quantitative and qualitative characters to exploit native and exotic demand. The success of improvement depends mainly on the morphological variability. The

1 Lecturer, Department of Agribusiness, Atish Dipankar University of Science \& Technology,Bangladesh.

2 Professor \& Dean, Faculty of Agriculture, Biological Science Biotechnology \& Textile, Atish Dipankar University of Science \& Technology, Bangladesh.

3 Executive Director, Bangladesh Science Foundation, Dhaka, Bangladesh.

4 Professor, Genetics \& Plant Breeding, Sher-e-Bangla Agricultural University, Dhaka, Bangladesh.

5 Scientific Officer, Genetics \& Plant Breeding, Bangladesh Agricultural Research Institute, Gazipur, Bangladesh.

6 Scientific Officer, Genetics \& Plant Breeding, Bangladesh Rice Research Institute, Gazipur, Bangladesh. 
morphological character of Gladiolus varies due to its genotypes. Rao and Negi (1994) studied the variability, heritability and genetic advancement on 12 biometric characters in gladiolus and found the highly significant differences due to genotypes. Negi and Raghava (1986) observed a higher phenotypic co-efficient of variation than the corresponding co-efficient of variation for plant height, flower number, corm number, spike length, spike diameter and rachis length. Negi et al (1978 a) conducted an experiment in gladiolus and concluded that the maximum variability was observed for plant height, corm number and flower yield. In addition to genotypic factors, the morphological character of gladiolus like all other flowering plants are directly or indirectly influenced by some environmental factors(temperature, humidity, rainfall, fog/dew, wind speed, soil texture, soil topography) as reported by several investigators. Owing to the above said facts and fallacies (environmental factors), the present study was undertaken to compare the variability among the genotypes and to find out the suitable genotypes of gladiolus flower for increasing the production of flower, corm and cornel of gladiolus in order to meet the demand of flower lovers.

\section{MATERIALS AND METHODS}

The present experiment was carried out at the Commercial Flower Garden of Society and Human Development Organization, Tangail (SAHDOT) during the period from November'2008 to October'2009 to investigate the morphology of different gladiolus genotypes. The experiment examined five gladiolus genotypes. The studied characteristics were plants height, leaves, flowers, corm and cormels. The experiment was laid out in a randomized Complete Block Design each having 5 replications. The unit plot size was $2 \mathrm{~m} \times 1 \mathrm{~m}$. The experimental plot was opened in the first week of November 2008, and was exposed to the sun for a weak. After a week manures (cow dung) along with all other fertilizers were applied accordingly. The entire amount of cow dung and Triple Super Phosphate was applied during final land preparation. Muriate of Potash was applied in two installments at 25 and 50 days after planting of corms. Nitrogen was applied as per treatment at 15, 30 and 45 days after germination. Medium sized(two years aged) corms were planted at $6 \mathrm{~cm}$ depth in furrows on 5th November 2008 following the row to row spacing of $25 \mathrm{~cm}$ and plant to plant spacing of $15 \mathrm{~cm}$. Different Intercultural operations like weeding, irrigation, earthing up, stacking, pesticide and fungicide application were performed as and when necessary. The spikes were cut when one or two lower most florets showed color but still in tight bud stage (Mukhopadhyay, 1995). Harvesting of corms and cormels were performed only when leaves turned into brown (Mukhopadhyay, 1995). Data were collected and recorded from the selected genotypes in accordance with different parameters. The recorded data on the selected parameters were set for statistical analysis. The mean for collected data for each treatment was calculated.

\section{Plant height}

\section{RESULTS AND DISCUSSION}

The plant height varied enormously due to genotype (Table1 and Plate1). The tallest plant $(58.65 \mathrm{~cm})$ was in Yellow and the shortest one was in Orange $(46.52 \mathrm{~cm})$. The variation observed in plant height among the genotypes might be due to difference in genetically constituents as well as environmental effects. 


\section{Leaf length}

Leaf length was affected by genotypes and varied from $33.36 \mathrm{~cm}$ to $42.25 \mathrm{~cm}$ (Table 1). The longest leaf $(42.25 \mathrm{~cm})$ was recorded in Yellow followed by Violet $(42.05)$, White $(37.35 \mathrm{~cm})$ and Orange $(35.50 \mathrm{~cm})$, while the shortest one was recorded for Red $(33.36 \mathrm{~cm})$. Wide variation in leaf length amongst some genotypes of gladiolus was observed by Singh, and Dadlani. (1990).

\section{Leaf breadth}

There was variation $(1.65 \mathrm{~cm}$ to $3.05 \mathrm{~cm})$ in leaf breadth amongst the genotypes (Table 1$)$. The Yellow genotype attained the maximum leaf breadth $(3.05 \mathrm{~cm})$, which was followed by White genotype $(2.90 \mathrm{~cm})$, Violet $(2.66 \mathrm{~cm})$ and Red $(2.50 \mathrm{~cm})$. Breadth of leaf was found to be minimum in Orange $(1.65 \mathrm{~cm})$. Bhagur (1989) recorded significant variation in respect of leaf breadth amongst thirty genotypes of gladiolus. He found that leaf breadth varied from 1.3 to $4.5 \mathrm{~cm}$.

Table1. Morphological (Phonological) characteristics of different genotypes of gladiolus

\begin{tabular}{|l|l|l|l|l|l|}
\hline Genotypes & $\begin{array}{c}\text { Color of } \\
\text { genotypes }\end{array}$ & $\begin{array}{c}\text { Plant } \\
\text { height(cm) }\end{array}$ & $\begin{array}{c}\text { Length of } \\
\text { leaves(cm) }\end{array}$ & $\begin{array}{c}\text { Breadth of } \\
\text { leaves(cm) }\end{array}$ & $\begin{array}{c}\text { No. of average } \\
\text { leaves per plant }\end{array}$ \\
\hline GL-21 & White & 55.20 & 37.35 & 2.90 & 12.25 \\
\hline GL-04 & Yellow & 58.65 & 42.25 & 3.05 & 8.50 \\
\hline GL-16 & Orange & 46.52 & 35.50 & 1.65 & 8.65 \\
\hline GL-12 & Violet & 56.97 & 42.05 & 2.66 & 8.70 \\
\hline GL-22 & Red & 46.65 & 33.36 & 2.50 & 10.90 \\
\hline
\end{tabular}

\section{Number of leaves}

Significant variation was observed as to the number of leaves amongst the genotypes (Table 1). The maximum number of average leaves (12.25) was obtained from the White genotype which was followed by Red genotype (10.90), Violet (8.70) and Orange (8.65) whereas in Yellow genotype attained the minimum number of leaves (8.50). This variation might be due to genotype as well as some known and/or unknown environmental factors.

Plant produces food materials through the process of photosynthesis. With the increasing number of leaves, photosynthesis generally increases, and plant can produce more food that influences the growth and development of the plant. So, genotypes that can produce more leaves have more plant growth leading to higher yield.

\section{Days to reach $\mathbf{5 0 \%}$ spike initiation}

Marked differences were observed for days to $50 \%$ spike initiation amongst the genotypes under investigation (Table 2 \& Plate 2). The Yellow genotypes took maximum days (70 days) to reach 50\% spike initiation which was followed by Orange (67 days), Red (65 days) and Violet (62 days). The minimum number of days (60 days) was taken by the White genotype. In a varietal trial, Ashwath and Parthasarathy (1994) reported that the white varieties required 40-70 days to 50\% spike initiation which was in consonance with majority of the genotypes under investigation. Singh and Dadlani(1990) recorded 38.7 days to 50\% spike initiation in case of Apsara as an earliest genotype. The differences in days to reach $50 \%$ spike initiation might be due to the genetical factors of the concerned genotype. 


\section{Spike length}

Significant variation in respect of spike length was found among the genotypes (Table 2). The longest spike $(92.05 \mathrm{~cm})$ was produced by White genotype which was followed by Yellow, violet and $\operatorname{Red}(73.90,72.50$ and $65.65 \mathrm{~cm}$ respectively) ones while the shortest spike(59.63cm) was produced by Orange genotype. Bhagur(1989) found that spike length ranges from 61.60 to $137.97 \mathrm{~cm}$ in varietal evaluation of gladiolus.

\section{Rachis length}

A great deal of genotypic variation in rachis length was observed (Table 2) and varied from 25.66 to $47.30 \mathrm{~cm}$. The highest rachis length was observed in White $(47.30 \mathrm{~cm})$, which was followed by Red $(36.62 \mathrm{~cm})$, Yellow $(34.40 \mathrm{~cm})$ and Violet $(28.32 \mathrm{~cm})$. The lowest rachis length $(25.66 \mathrm{~cm})$ was observed in Orange genotype. Anuradha and Gowda (1994) reported that rachis length was highest $(51.77 \mathrm{~cm})$ in Deep Red (GL-06) genotype.

\section{Number of flower}

Variation in average number of flower per plant amongst the genotypes was ranged from 8.40 to 14.25(Table 2). The highest number of flower per plant was produced by Whiteone (14.25). The Orange genotype (8.40) produced the lowest number of flower per plant. The number of flowers per plant varied from 5.33 to 20.00 as reported by Negi et al., (1982) from their experiment at the Hariana Agricultural University Farm, Hissar, India. Lal and Plant (1989) recorded 8 flowers per plant in GL06 to 18 flowers in GL-15 in a gladiolus trail conducted at Maharastra in India.

\section{Weight of single stick}

Genotypes had displayed a wide range of variability amongst them in respect of stick weight. It ranged from in 26.47 to 53.85 gm (Table 2). Highest stick weight was recorded for white genotype White (53.87 g) which was followed by Yellow (45.85g), Red (39.65g) and Violet (37.30g). The lowest stick weight producer genotype was Orange (26.47g).

Table2. Morphological characteristics of different genotypes of Gladiolus

\begin{tabular}{|l|l|l|l|l|l|l|l|l|l|}
\hline $\begin{array}{l}\text { Sl. } \\
\text { No. }\end{array}$ & $\begin{array}{l}\text { Color } \\
\text { genotype }\end{array}$ & $\begin{array}{l}\text { Days to } \\
\text { reach } \\
\mathbf{5 0 \%} \\
\text { spike } \\
\text { initiation }\end{array}$ & $\begin{array}{l}\text { Length } \\
\text { of } \\
\text { flower } \\
\text { (cm) }\end{array}$ & $\begin{array}{l}\text { Breadth } \\
\text { of } \\
\text { flower } \\
\text { (cm) }\end{array}$ & $\begin{array}{l}\text { Wt. of } \\
\text { flower } \\
\text { (g) }\end{array}$ & $\begin{array}{l}\text { Wt. } \\
\text { of } \\
\text { single } \\
\text { stick } \\
\text { (g) }\end{array}$ & $\begin{array}{l}\text { Length } \\
\text { of spike } \\
\text { (cm) }\end{array}$ & $\begin{array}{l}\text { Length } \\
\text { of } \\
\text { rachis } \\
\text { (cm) }\end{array}$ & $\begin{array}{l}\text { Average } \\
\text { Flowers } \\
\text { per plant }\end{array}$ \\
\hline 01 & White & 60 & 9.42 & 9.09 & 7.14 & 53.87 & 92.05 & 47.30 & 14.25 \\
\hline 02 & Yellow & 70 & 9.75 & 9.41 & 7.25 & 45.85 & 73.90 & 34.40 & 9.80 \\
\hline 03 & Orange & 67 & 8.39 & 6.90 & 4.54 & 26.47 & 59.63 & 25.66 & 8.40 \\
\hline 04 & Violet & 62 & 9.28 & 9.28 & 6.20 & 37.30 & 72.50 & 28.32 & 9.90 \\
\hline 05 & Red & 65 & 8.78 & 8.52 & 6.51 & 39.65 & 65.65 & 36.62 & 10.15 \\
\hline
\end{tabular}




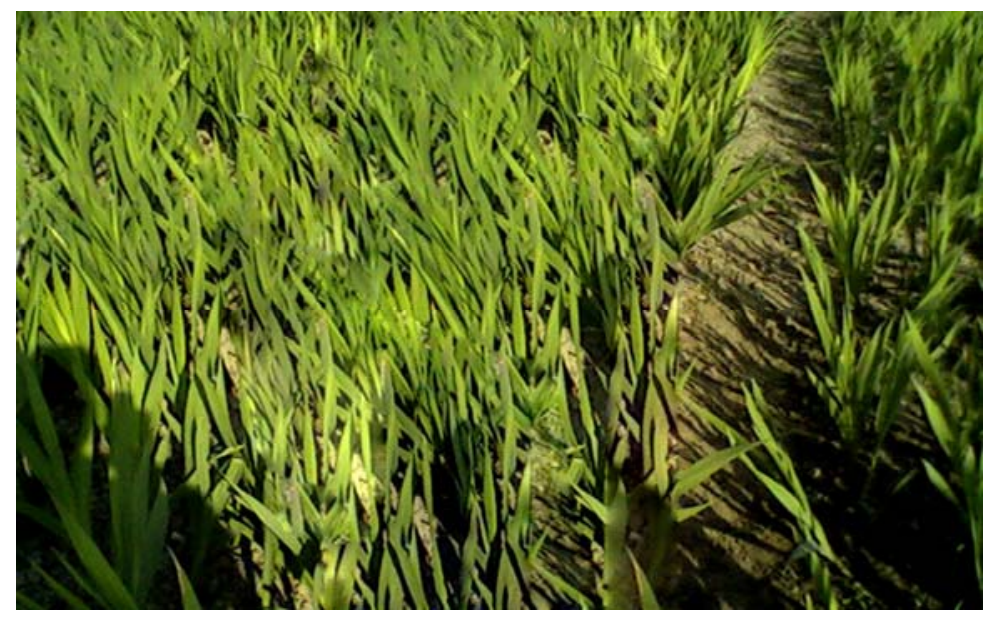

Fig: Field View at Vegetative Stage of Gladiolus Flower
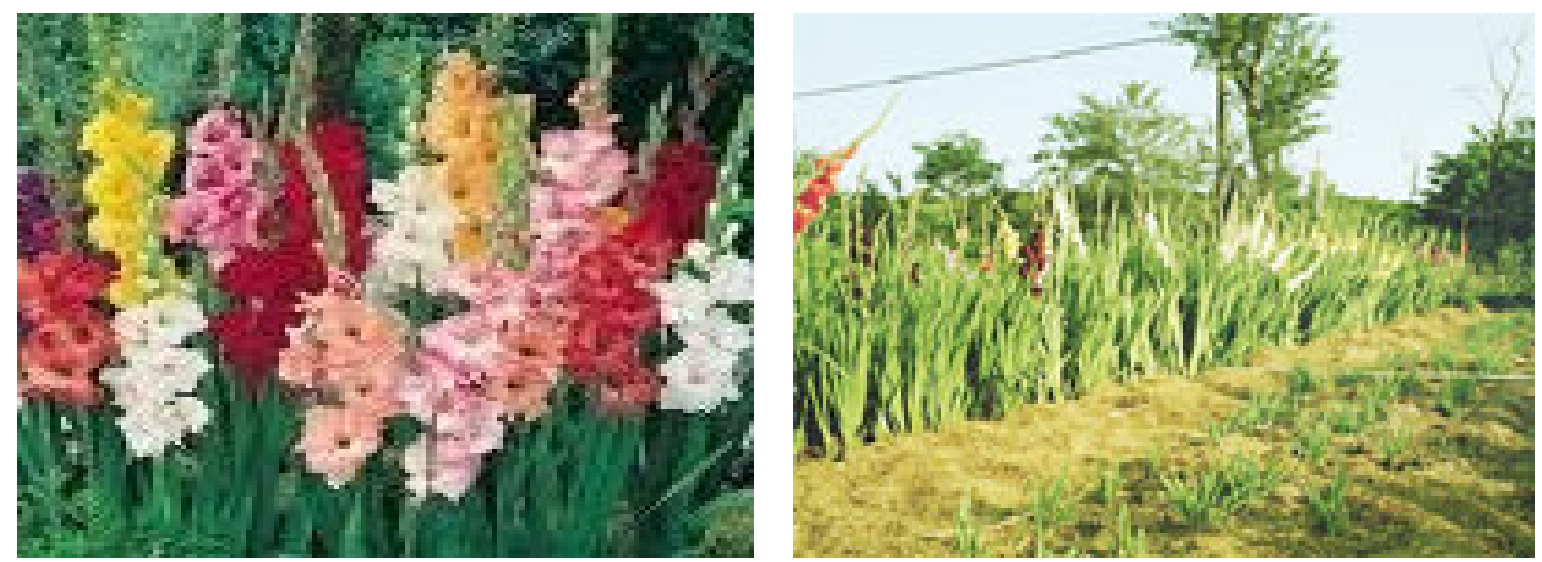

Fig: Field View at Flowering Stage of Gladiolus Flower

Plate-1: Vegetative \& Reproductive (Flowering) Stage of Gladiolus Flower

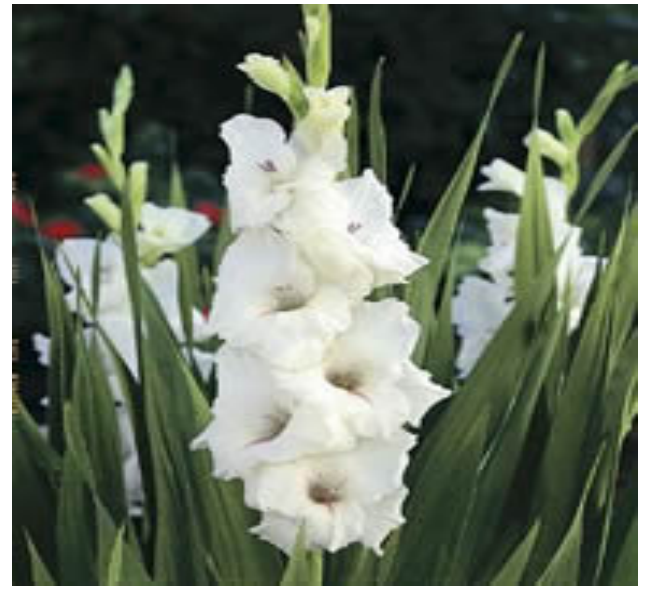

Fig: White Genotype

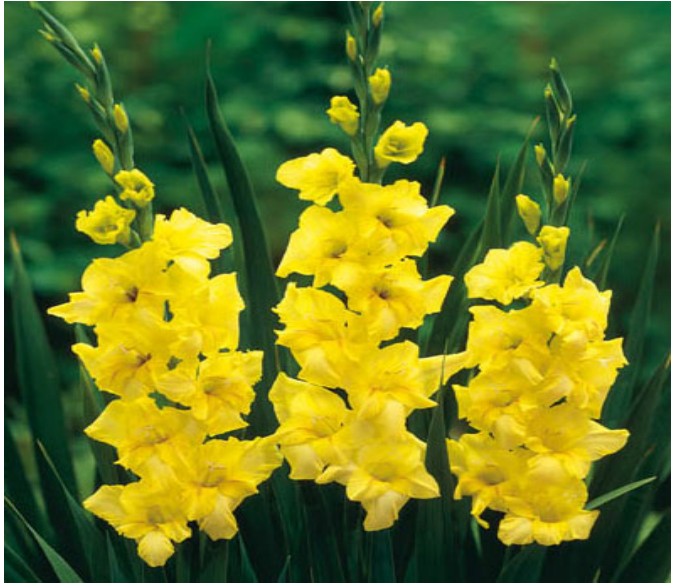

Fig: Yellow Genotype 


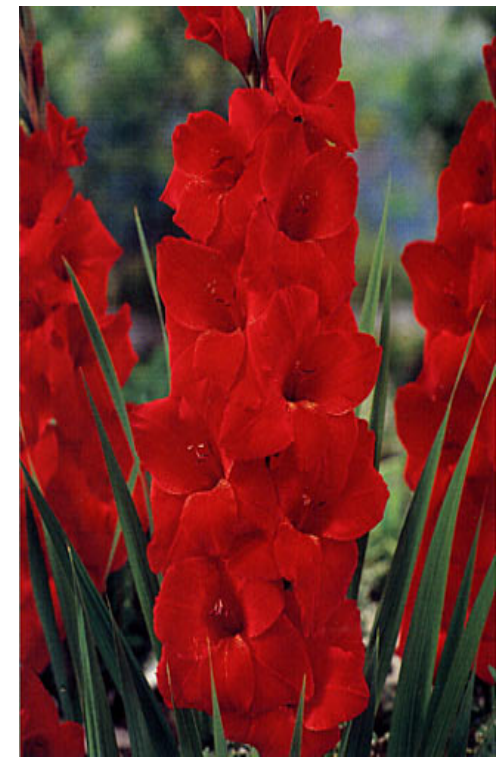

Fig: Red Genotype

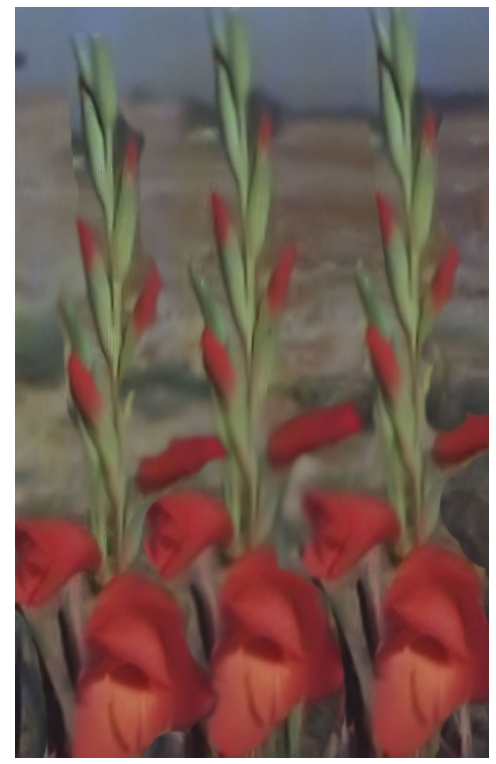

Fig: Orange Genotype

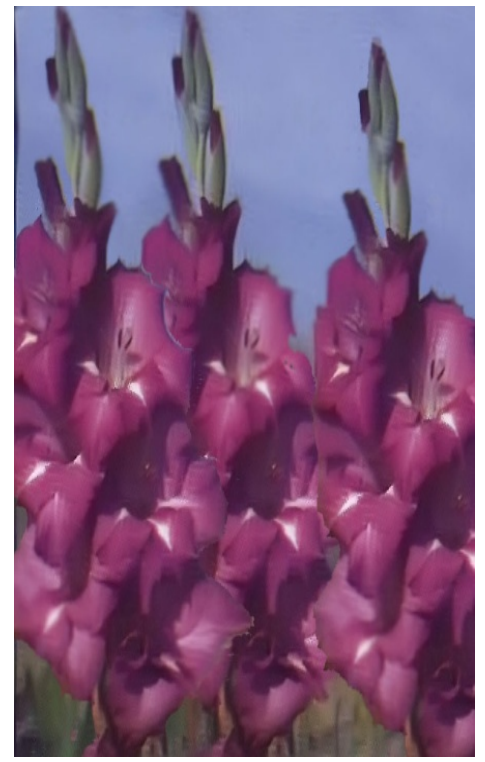

Fig: Violate Genotype

\section{Plate-2: Flowers of different Gladiolus Genotype.}

\section{Number of corms}

Data recorded in respect of corm production of five genotypes of gladiolus are presented in Table 3. The number of corms produced per plant was the highest in Orange genotype (2.55) followed by Red (1.70), Violet (1.40) and Yellow (1.25) ones. The lowest number of corms (1.15) was produced by the White genotype. The variation observed in corm production amongst the genotypes might be due to difference in genetically constituents as well as environmental factors. Variation (1.0 to 4.0m) in corm production amongst some genotypes of gladiolus was observed at Bangalore in India by Anuradha and Gowda (1994).

\section{Weight of corms}

Genotypes had displayed a wide range of variability amongst them in respect of corm weight (Table 3\& Plate 3). It ranged from 18.16 to $36.76 \mathrm{~g}$. The highest corm weight (36.76g) was recorded from the Yellow genotype which was followed by White (30.92gm), Violet (26.30g) and Red (25.30g) ones. The lowest corm weight per plant was obtained from the Orange genotype (18.16g). Sharma and Sharma (1984) reported that corm weight was the highest in Yellow genotype (67g) and lowest in GL25(18g) genotype which was more or less in consonance with the present investigation

\section{Number of cormel per plant}

Number of cormel per plant differed significantly affected by genotypes (Table 3). The highest number of cormels per plant was obtained from the White genotype (43.20) which was followed by Violet (28.85), yellow (27.20) and Orange (25.75) one. The Red genotype (25.70) produced the lowest number of cormels per plant. Misra and Saini (1990) recorded 5 to 20 cormel per plant in gladiolus genotypes in a trial conducted at Bangalore, India.

\section{Weight cormel per plant}

Genotypes had displayed a range of variability among them in respect of cormel weight per cormel(Table 3\& Plate 3)). It ranged from 5.20 to $6.40 \mathrm{~g}$. The highest cormel weight was recorded in genotype White (6.40g) which was closely followed by Yellow (6.39g), Violet (5.75g) and Red (5.30g).The Orange genotype $(5.20 \mathrm{~g})$ produced the lowest weight of cormel per corm. Negi et al., 
(1982) reported that cormel weight in gladiolus genotypes ranged from 5.2 to $17.0 \mathrm{~g}$ which is more or less similar result with the findings of the present investigation.

Table-3. Corm and cormel characteristics of gladiolus flower

\begin{tabular}{|l|l|l|l|l|l|l|}
\hline Sl.No. & $\begin{array}{c}\text { Color of } \\
\text { genotype }\end{array}$ & $\begin{array}{c}\text { Av. No. } \\
\text { of corm / } \\
\text { plant }\end{array}$ & $\begin{array}{c}\text { Av. } \\
\text { Breath of } \\
\text { corm } \mathbf{( c m )}\end{array}$ & $\begin{array}{c}\text { Wt. of } \\
\text { corm (g) }\end{array}$ & $\begin{array}{c}\text { Av. No. of } \\
\text { cormel/ plant }\end{array}$ & $\begin{array}{c}\text { Wt. of } \\
\text { cormel (g) } \\
\text { / plant }\end{array}$ \\
\hline 01 & White & 1.15 & 3.24 & 30.92 & 43.20 & 6.40 \\
\hline 02 & Yellow & 1.25 & 3.81 & 36.76 & 27.20 & 6.39 \\
\hline 03 & Orange & 2.55 & 2.74 & 18.16 & 25.75 & 5.20 \\
\hline 04 & Violet & 1.40 & 3.17 & 26.30 & 28.85 & 5.75 \\
\hline 05 & Red & 1.70 & 3.26 & 25.30 & 25.70 & 5.30 \\
\hline
\end{tabular}

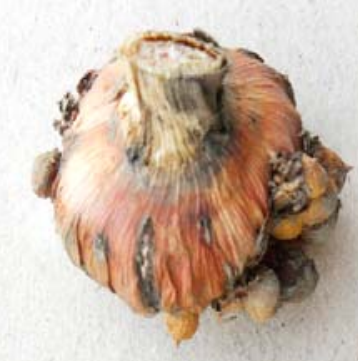

Fig: Corm of White Genotype

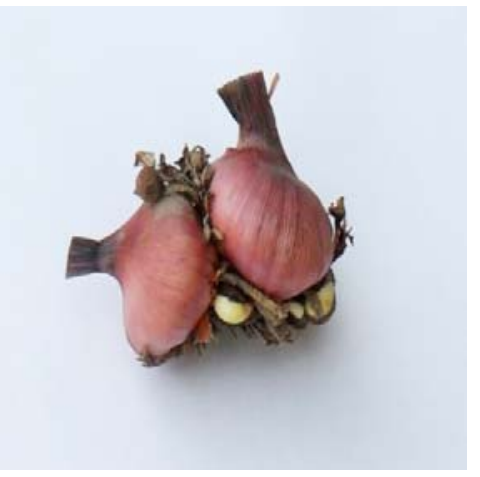

Fig:Corm of Violet Genotype

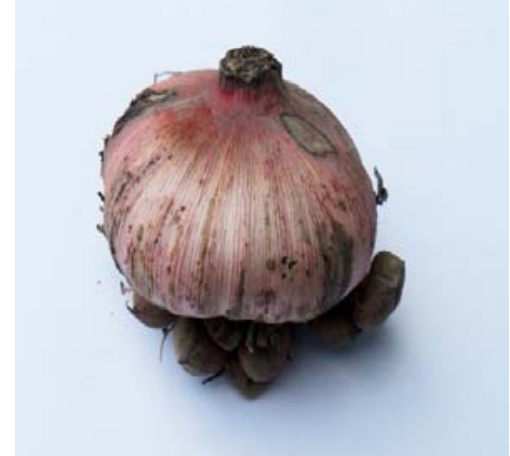

Fig:Corm of Yellow Genotype

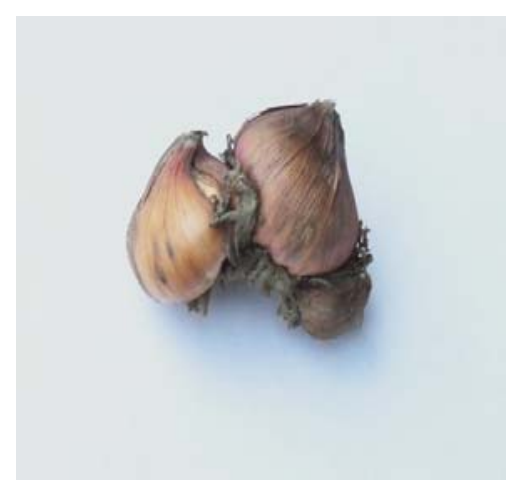

Fig:Corm of Red Genotype

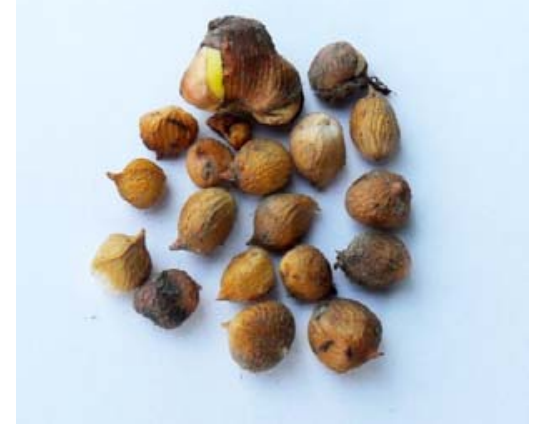

Fig: Cormels of Gladiolus Flower
Fig:Corm of Orange Genotype

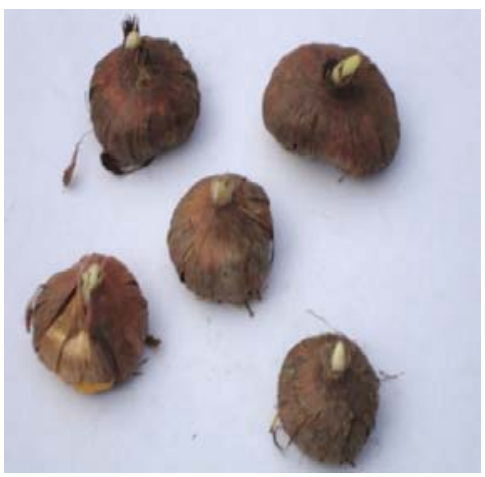

Fig: Sprouted Corm of Gladiolus

Plate-3: Corms and Cormels of different Gladiolus genotype 


\section{REFERENCES}

Anuradha, S. and J.V. Gowdha. (1994). Correlation studies in Gladiolus. [In: Floriculture-Technology, Trades and Trends. (Eds.) Prakash, J. and K. R. Bhandry.] Oxford and IBH Publishing Co. Pvt. Ltd. Calcutta. pp.285-287.

Ashwath, G. and V. A. Parthasarathy. (1994). Genetic variability in some quantitative characters of gladiolus. [In: Floriculture-Technology, Trades and Trends. (Eds.) Prakash, J. and K. R. Bhandry.] Oxford and IBH Publishing Co. Pvt. Ltd. Calcutta. pp.288-290.

Bhagaur, H. S. (1989). Studies of variability and genetic component of flower in exotic varieties of gladiolus. Ph.D.thesis, Kanpur University, Kanpur.

Lal, S. D. and C. C. Plant. (1989). Some newly developed hybrids of gladiolus. Progressive Horticulture. 21:189-93.

Mirsa, R.L. and H. C. Saini. (1990). Genotypic and Phenotypic variability in gladiolus. J. Hort. Sci., 45:427-34.

Mollah, M. S. khan, F. N.and Amin, M. M (2002). Gladiolus. Landscape, Ornamental and floriculture division. HRC, BARI, Gazipur, Bangladesh. pp.13-14.

Mukhopadhyay, A. (1995). gladiolus. Publications and Information division, ICAR New Delhi.p.35.

Negi, S.S., S.P.S. Raghava and T.V.R.S. Sharma. (1982). New cultivars of Gladiolus. Indian Horticulture. 26(4): 19-20.

Negi, S.S., T.V.R.S. Sharma, S.P.S. Raghava and P.R. Ramachandra. (1978a). Studies on heritability and interrelationship among various characters in gladiolus. $20^{\text {th }}$ Int. Hort. Congr., Sydney, Australia, Abstr. 1982.

Negi, S.S., T.V.R.S. Sharma, S.P.S. Raghava and V.R. Srinivasan, (1986). Variability studies in Gladiolus. Indian J. Hort., 39: 269-72.

Rao, T.M. and T. Jamaicn. (1994). Quantitative and qualitative evaluation of Fusarium and tolerant hybrids of gladiolus. [In: Floriculture Technology, Trades and Trends. (Eds.) Prakash, J. and K. R. Bhandry.] Oxford and IBH Publishing Co. Pvt. Ltd. Calcutta. pp.265-268.

Sharma, A.N. and S.C. Sharma, (1984). Some promising gladiolus hybrids. NAGC Bull., No. 157. pp.51-52.

Singh, and Dadlani. (1990). Research Highlights (1971-1985). All Indian Coordinated Floriculture Improvement Project, ICAR, New Delhi. 